Ilmu Pertanian (Agricultural Science)

Vol. 4 No. 2 August, 2019: 71-75

Available online at http://journal.ugm.ac.id/jip

DOI: doi.org/10.22146/ipas.42124

\title{
Correlation of Secondary Metabolites of Leaf with Resistance to Leaf Rust (Hemileia vastatrix) on Several Arabica Coffee Clones
}

\author{
Gatot Subroto*, Dwi Erwin Kusbianto, Sholeh Avivi, Slameto and Setiyono \\ Faculty of Agriculture, Universitas Jember \\ Jln. Kalimantan No. 37, Krajan Timur, Sumbersari, Jember, East Java 68121, Indonesia \\ *Corresponding author: gatots.faperta@unej.ac.id
}

Received: 25 th December 2018; Revised: $16^{\text {th }}$ May 2019; Accepted: $21^{\text {st }}$ May 2019

\begin{abstract}
Indicator of coffee resistance to leaf rust attack (Hemileia vastatrix) is needed to select superior coffee plants resistant to biotic stress. This study aimed to determine the relationship between the content of secondary metabolites and the intensity of leaf rust attack, therefore, it becomes a reference in the selection of future coffee plants. The experimental design used was a completely randomized design (CRD) with five coffee clones, including Komasti Maragogik, Usda, Andong sari, and HDT (Hybrido de Timor) as treatment. Each treatment consisted of 3 replications, and each replication consisted of 2 sample plants. Observations were made by observing the intensity of the attack, and plant metabolites such as phenolic content, flavonoids content, and antioxidant activity observed when the leaves had been attacked by H. vastatrix. The correlation analysis between leaf rust attack intensity and the plant metabolites showed a relationship between each observation variable. Flavonoid content in certain conditions can be used as an indicator to get Arabica coffee plants that are resistant to the attack of leaf rust.
\end{abstract}

Keywords: Arabica coffee; leaf rust; Secondary metabolites.

\section{INTRODUCTION}

The development of arabica coffee aims to provide the availability of planting material resistant to leaf rust but still has high productivity. In order to obtain more uniform plants, the recommended Arabica coffee planting material is clonally propagated. Coffee is mostly cultivated by smallholder plantations because coffee cultivation is quite easy. Besides, coffee can also grow in almost all parts of Indonesia (Ditjenbun, 2014). The coffee cultivar mostly produced around the world is Arabica coffee due to its superior taste and aroma. Coffee trade in the world market is currently dominated by Arabica coffee with a market share of more than 75 percent, while the rest is filled with Robusta coffee (Malian, 2004). Arabica coffee has a price that is almost double that of Robusta. Coffee production in 2015-2017 decreased to 639.4 tons, 639.3 tons and 637.5 tons, respectively (BPS, 2017).

Disorders of leaf rust attack is a major problem in coffee crop because it influences the plant growth, hence, decreases the yield of coffee beans. Wide-spread spots of leaf rust significantly lead to the decreasing area of photosynthesis, thus decreasing the plant growth. The number of deciduous leaves as a further symptom of this disease causes the number of flowers formed to decrease, which results in a decrease in the amount of coffee beans (Mahfud, 2012). The disease results in plant damage and death as well as huge yield losses.

Plants have a mechanism to overcome biotic stresses, one of which is by increasing the content of secondary metabolites in the affected tissue. Endurance excretion compounds that are usually in the form of phenolic compounds, flavonoids or changes in antioxidant activity known as anti-fungal compounds (Berlian et al., 2016). Sampling of leaves for analysis of secondary metabolite content was then correlated with the level of leaf rust attack on each plant. Plant resistance to leaf rust was also obtained by looking at the correlation of the observed parameters. The objective of this research was to obtain a statistical model of relationship betwen disease intensity and metabolites content which can be used as indicators in the slection of coffee germplasm resistant to leaf rust (H. vastatrix). 


\section{MATERIALS AND METHODS}

Plant endurance tests on the resistance of leaf rust disease were carried out in October - December 2018 in the Plant Disease Laboratory and Green House Agrotecnopark of the Faculty of Agriculture, University of Jember. The testing of the selected Arabica coffee clones in this experiment was arranged in a Completely Randomized Design (CRD) according to Gomez and Gomez (1976) with several coffee clones as treatments. This test examined five arabica coffee clones, namely Komasti, Maragogik, USDA, Andong sari, and HDT (Hybrido de Timor) clones consisting of 10 replications within each treatment and two sample plants in each replication. The prepared suspension of $H$. vastatrix spora was sprayed on the leaves of coffee clones with spraying concentration of $10^{-3}$ (Mudyiwa et al., 2017) H.vastatrix $\mathrm{ml}^{-1}$ using a sprayer. Incubation was carried out for 4 weeks and symptoms in the leaves were observed.

The intensity of the disease attack was calculated by taking leaves of the sample plant and assessing the infected leaves based on the disease score used according to the criteria as showed at Figure 1. The calculation of the severity of the disease was carried out using the formula:

$$
\mathrm{P}=\frac{\sum(n \times v)}{N \times Z} \times 100 \%
$$

A month after innoculation, the secondary metabolite observed was the total phenolic content of the leaves of coffee plant seeds. Determination of total phenolic content was performed according to the modified method by Singleton and Rossi (1965). Each of $0.1 \mathrm{ml}$ of $200 \mu \mathrm{g} \cdot \mathrm{ml}^{-1}$ coffee leaf extract was added to the test tube. 0.1 Folin solution Ciocalteu reagent $50 \%$ was added to the tube and vortexed for 1 minute. The solution was added with $2 \mathrm{ml}$ sodium carbonate $\left(\mathrm{Na}_{2} \mathrm{CO}_{3}\right) 2 \%$ solution. This mixture was stored in a dark room for 30 minutes.
The absorbance of the extract solution was read at a $750 \mathrm{~nm}$ wavelength with a UV-Vis spectrophotometer. The results were expressed as mg gallic acid per $\mathrm{kg}$ extract (Ismail et al., 2012).

The data obtained were analyzed using analysis of variance. Data showing significant difference between treatments then were tested with the DMRT (Duncan Multiple Range Test) according to Gomez and Gomez (1976). The value of the correlation coefficient was calculated using the formula:

$$
r_{x y}=\frac{N \cdot \sum x \cdot y-\left(\sum X\right)\left(\sum Y\right)}{\sqrt{\left[N \cdot \sum X^{2}-\left(\sum X\right)^{2}\right]\left[N \cdot \sum Y^{2}-\left(\sum Y\right)^{2}\right]}}
$$

The significance of the coefficient of correlation value was tested with the t-test (Gomez and Gomez, 1976) with the formula as follows:

$$
\mathrm{t} \text {-test }=t=r \cdot \frac{\sqrt{N-2}}{\sqrt{1-r^{2}}}, \mathrm{t} \text { tabel }(\alpha \% ; \mathrm{n}-2)
$$

\section{RESULTS AND DISCUSSION}

Research on the correlation between phenol content in leaves and the resistance to the leaf rust (Hemileia vastatrix) on seedlings of several Arabica coffee clones started from the inventory of superior germplasm sources around the Ijen-Raung area. Coffee in the Ijen-Raung area is known as arabica coffee with the best aroma in East Java. There are 4 gardens with specific ecosystems, each of which is the location for extracting the germplasm of coffee clones. Among them are Kayumas, Kalisat Jampit, Pancur, and Belawan plantation.

The results of phenolic analysis showed that the phenolic content, flavonoids content, and antioxidants activities were still high in healthy plants (not attacked by leaf rust). It's different when the plants started to be infected with leaf rust. Plants with early-stage of leaf rust (level 1 attack level) had a lower phenol content. The phenolic content of leaves decreased when the plant was attacked by leaf rust. The same condition also occured in the content of leaf

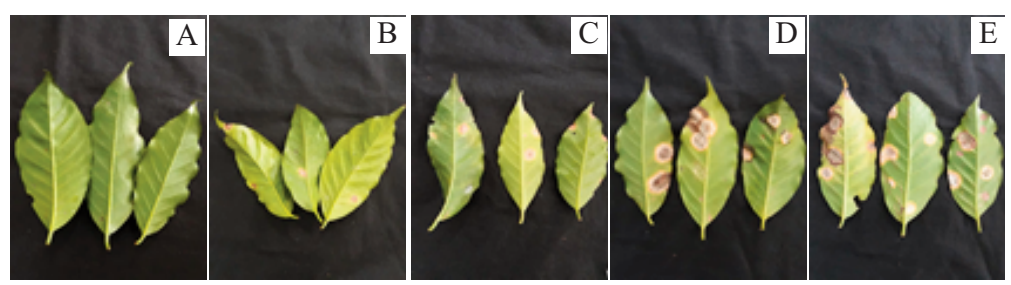

Figure 1. Scoring of the intensity of $H$. vastatrix attacks on coffee leaves in a sequential field in HDT coffee: (A) score 0 (normal leaves/without leaf rust spot); (B) score 1 (10\% leaf rust spot); (C) score 2 (20\% leaf rust spot); (D) score 3 (30\% leaf rust spot); (E) score 4 (40\% leaf rust spot). 
Table 1. F-calculate variable percentage intensity variables $H$. vastatrix

\begin{tabular}{cccc}
\hline Source & F-test & \multicolumn{2}{c}{ Significantly } \\
\hline & & $5 \%$ & $1 \%$ \\
Treatment & $4.08^{* *}$ & 2.59 & 3.79 \\
\hline
\end{tabular}

Table 2. Analysis of phenol content, flavonoid content, and antioxidant activities and fungal intensity of $H$. vastatrix

\begin{tabular}{lccc}
\hline Clone & $\begin{array}{c}\text { Phenol content } \\
\left(\mathrm{mg} . \mathrm{g}^{-1}\right)\end{array}$ & $\begin{array}{c}\text { Flavonoid } \\
\left(\mathrm{mg}^{-1}\right)\end{array}$ & $\begin{array}{c}\text { Antioxidant } \\
\text { activities (\%) }\end{array}$ \\
\hline A : Komasti & 5.329 & 9.810 & 48.199 \\
B : Maragogip & 6.011 & 11.606 & 55.174 \\
C : USDA & 7.628 & 17.590 & 56.489 \\
D : Andungsari & 6.799 & 13.587 & 55.174 \\
E : HDT & 12.860 & 20.914 & 62.207 \\
\hline
\end{tabular}

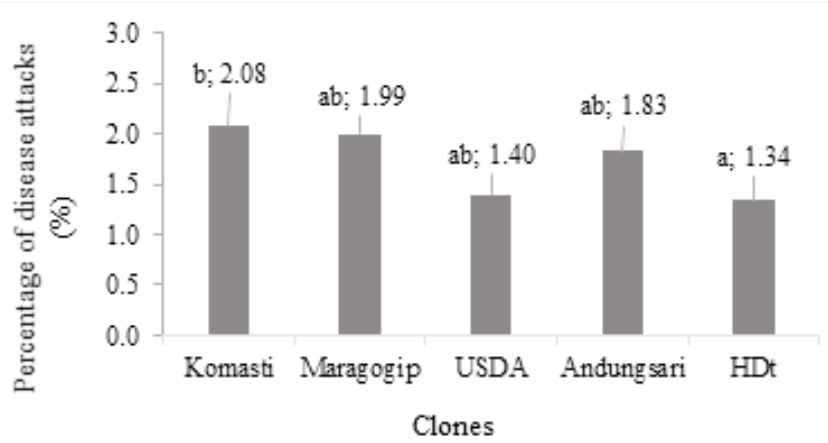

Figure 2. Intensity of leaf rust attacks by H.vastatrix

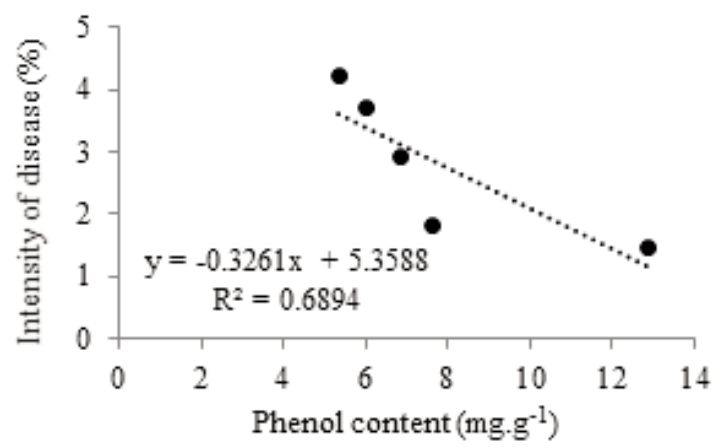

Figure 3. Regression analysis between phenolic content and disease intensity

flavonoids and antioxidant activity.

Based on the following results, it can be seen that each Arabica coffee clone had a different response to the disease attack caused by $H$. vastatlix. Responses from each Arabica coffee clone can be displayed according to the Figure 2. Figure 2 showed that clone E (HDT) had the lowest rate of attack on leaf rust disease, not significantly different from clones $\mathrm{B}, \mathrm{C}$, and $\mathrm{D}$ but significantly different from clones A (Komasti).

The correlation analysis between the intensity of the disease attack and phenolic content resulted $r$ value of -0.83 . However, based on the results of the

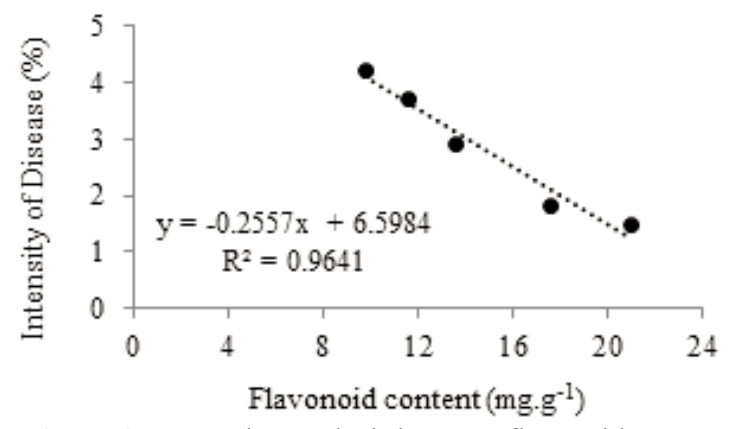

Figure 4. Regression analysis between flavonoids content and disease intensity

$\mathrm{t}$ test, it was found that the correlation was not significant as shown in the Figure 3.

The correlation analysis between the intensity of the disease attack and the flavonoids content showed r value of -0.98 and according to the $t$ test, the correlation was significant. This result meanas that the higher the intensity of the disease attack, the lower the flavonoids content in the leaves of Arabica coffee seedlings. This can be described as shown in the Figure 4.

The correlation analysis between the intensity of the disease attack and antioxidant activities resulted 


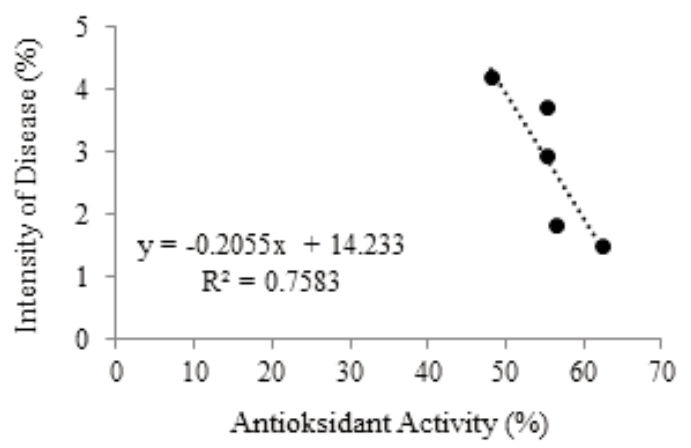

Figure 5. Regression analysis between antioxidant activities and disease intensity

$r$ value of -0.87 . However, based on the $t$ test, the correlation coefficient value was not significant. This result can be described as shown at Figure 5.

Based on the results of this research, showed that the flavonoids content can be used as an indicator for the selection of Arabica coffee seedlings resistant to the attack of leaf rust caused by the $H$. vastatrix fungus. Several studies show that flavonoids are natural anti-fungal compounds that are widely used in the health sector. Observation of flavonoid content in bay leaves (Bhaskara et al., 2012), basil leaves (Berlian et al., 2016), sembukan leaves (Abriyanto, et al., 2012) and beluntas leaves (Putri and Habib, 2007) also reported the same effects.

Flavonoids in leaves have been recognised as antimicrobial compounds, and the structures of flavonoids have properties of antifungal, antiviral and antibacterial activity (Panche et al., 2016). Another research reported that the activity of $H$. vastatrix presented a trend towards a decrease in phenolic compounds, but it was not significant. Under such conditions, plant defense metabolism depends entirely on the carbohydrate demand by fruits, the vegetative growth and the weather conditions (Salgado et al., 2008). Baiano and Previtali (2018) mentioned that spent coffee was analysed as a potential source of antioxidant highly correlated with total phenolics. According to Castaldo et al. (2018,) coffee contains phenol in the tissues which has antifungal that should be utilized. Generally, the plants have antifungal substances that can be used for the plant protection against phytopathogens.

The most effective coffe leaves extracts to prevent the micelial growth and conidial germination are Vernonia polysphaera, Syzygium aromaticum, and Allium sativum (Silva et al., 2014). Research by Nasrollahi and Yadegari (2016) showed that caffeine has antifungal effect on Candida albicans and combined with fluconazole (FLU) can enhance the antifungal activity of FLU against C. albicans (Silva et al.,
2014). Further research suggest that a combination of flavonoid and caffeine content can be used as an indicator of the resistance of each coffee clone against $H$. vastatrix.

\section{CONCLUSIONS}

Arabica HDT coffee clones had a lower intensity of leaf rust attack followed by Komasti clones. Flavonoid content can be used as an indicator to get Arabica coffee plants that are resistant to the attack of leaf rust ( $H$. vastatrix). The higher flavonoids content in leaves, the lower intensity of leaf rust caused by H. vastatrix.

\section{REFERENCES}

Antonietta, B. and M.A. Previtali. 2018. Coffee spent as a potential source of bioactive compounds. Acta Scientific Nutritional Health 2: 31-35.

BPS (Badan Pusat Statistik), 2017. Produksi Kopi di Indonesia tahun 2017. Badan Pusat Statistik : Jakarta.

Castaldo, L., G. Graziani, A. Gaspari, L. Izzo, C. Luz, Jordi Mañes, Mario Rubino, G. Meca and A. Ritieni. 2018. Study of the chemical components, bioactivity and antifungal properties of the coffee husk. Journal of Food Research, 7: 43-54.

Ditjenbun (Direktorat Jenderal Perkebunan). 2014. Budidaya tanaman kopi. www.ditjenbun. pertanian.go.id.

Gomez, K.A. dan A.A. Gomez. 1976. Statistical Procedures For Agricultural Research. John Wiley \& Sons, Inc. Canada

Harni R., E. Taufiq and B. Martono. 2015. Ketahanan pohon induk kopi liberika terhadap penyakit karat daun (Hemileia vastatrix B. et Br.) di Kepulauan Meranti. J. TDIP, 2: 35-42.

Hulupi R., S. Mawardi and Yusianto. 2012. Pengujian sifat unggul beberapa klon harapan kopi 
arabika di kebun percobaan Andungsari, Jawa Timur. Pelita Perkebunan, 28: 62-71.

Ibrahim M.S.D., D. Wahyuno and RR. S. Hartati. 2016. Ketahanan genotipe unggul beberapa spesies kopi terhadap penyakit karat daun (Hemileia vastatrix) asal Cisaat Sukabumi. Prosiding seminar. 865-874

Mahfud M.C. 2012. Teknologi dan strategi pengendalian penyakit karat daun untuk meningkatkan produksi kopi nasional. Pengembangan Inovasi Pertanian, 5: 44-57.

Mudyiwa, R.M., N. Mwatsiya, B. T. Manenji, P. Chidoko and C. Mahoya. 2017. Evaluation of different botanicals for the control of coffee leaf Rust (Hemileia vastatrix Berkeley and Broome). International Journal of Plant \& Soil Science, 14: 1-8.
Panche, A.N., A.D. Diwan and S. R. Chandra. 2016. Flavonoids: an overview. Journal of Nutritional Science, 5: 1-15.

Salgado, Paula R., J. L. Favarin, R.A. Leandro and O. Fontão de L. Filho. 2008. Total phenol concentrations in coffee tree leaves during fruit development. Sci. Agric. (Piracicaba, Braz.), 65: 354-355.

Silva, J.L., Souza P.E., Monteiro F.P., Freitas, M.L.O., Silvia, M.B. Jr., Belan, L.L. 2014. Antifungal activity using medicinal plant extracts against pathogens of coffee tree. Rev. Bra. Pl. Med., Campinas, 16: 539-544. 